\title{
The Impact of Selected Personality Skills on Intercultural Interaction and Communication of Students of Social Pedagogy in the Czech Republic
}

\author{
Irena Balaban Cakirpaloglu, Karla Hrbackova
}

\begin{abstract}
This paper focuses on the issue of intercultural competencies of university students who are preparing to work in assisting professions. In recent years, the Czech Republic has become a significant destination for many people from different cultural environments, and there is a growing need for workers in assisting professions to be able to respond flexibly and adequately to the changing living conditions of multicultural coexistence. The primary objective of this study is to analyze the preparedness of students in assisting professions for intercultural competencies. Intercultural competences include several essential skills for working successfully with diversity. Taking into account the primary objective of this research, a pilot study was conducted among students of Social Pedagogy at the Faculty of Humanities at Tomas Bata University in Zlín in the academic year 2017/2018. The research sample consisted of 116 students. To obtain the data, we used the Cross-Cultural Adaptability Inventory (CCAI) by Kelley and Meyers. The inventory maps strengths and weaknesses in 4 skill areas: Emotional Resilience, Flexibility / Openness, Perceptual Acuity and Personal Autonomy. This inventory also examines individual ability to succeed in intercultural interaction and communication. The results obtained from the survey were statistically processed and analyzed using the relevant statistical methods. The results of the survey point to the fact that students of Social Pedagogy achieve average to below average results in individual skill areas. At the same time, significant differences have been detected among the students with work experience in a multicultural environment and those with no experience.
\end{abstract}

Keywords - Cross-Cultural Adaptability Inventory, diversity, intercultural competences

\section{INTRODUCTION}

During the last twenty years, the Czech Republic has slowly but surely become a multicultural society. Mobility, migration, and intercourse of different cultures appear to be one of the significant attributes of contemporary society. These changing living conditions also necessarily relate to the ability to operate successfully within a community. The skills that an individual needs to be successful today are fundamentally different from those that were requested 15 or 20 years ago. Increasing

Irena Balaban Cakirpaloglu, Ph.D., Faculty of Humanities, Tomas Bata University, Zlin, Czech Republic,

Karla Hrbackova, Ph.D., Faculty of Humanities, Tomas Bata University, Zlin, Czech Republic, international mobility and migration, the internalization of work opportunities and communities are the most striking progressive changes in recent years. In the context of the globalization of the contemporary world, Chen and Starosta [1] have identified five essential trends, and they both agree that intercultural communication skills become an indispensable component of the personality of a modern individual. Among these trends, they particularly highlighted the tremendous development of communication and transport technology, the globalization of the world economy, the migration of people, the growth of multiculturalism and, finally, the de-emphasis of national states. These factors have gradually led to the interconnection of people from different parts of the world and the necessity of working together from different cultural backgrounds. Also, Morvayová states that one of the preconditions for overcoming or preventing the emergence of barriers and diversity issues is the development of interpersonal sensitivity and social skills of individuals [2]. Other authors, such as Morgensternová and Sulová also confirm the importance of intercultural sensitivity in contemporary society to succeed in cross-cultural interaction and communication [3].

\section{A. Development of Intercultural Sensitivity and Intercultural Competencies}

Development of intercultural sensitivity requires to have personally reflected experience, as well as the willingness of an individual to get to know reality from a different point of view. Authors Morvayová and Moree agree that intercultural sensitivity can be developed on the basis on thorough self-reflection and introspection and at the same time reflection of various social phenomena, mechanisms, and processes, resulting in an increased ability to take a conscious and non-stereotypical attitude towards human differences [2]. In other words, an individual should have some intercultural competencies that, among other things, extension of intercultural sensitivity can help with orientation in today's world. Morgensternová and Šulová [3] further point out that acquiring intercultural competences is a complicated and long-term process that includes predispositions, uniquely personal and situational factors, as well as cross-cultural 
confrontation. These attributes result in the formation of cross-cultural experiences, intercultural learning, and intercultural understanding. Bennett [4] also provides a general interpretation of intercultural competences, namely that it is the ability to communicate effectively in a cross-cultural situation and act adequately in different intercultural contexts. Fantini [5] defines intercultural competences as a complex of capabilities needed for adequate and reasonable performance in interaction with others who are linguistically and culturally different.

Morgensternová and Šulová [3] describe a three-component model defining intercultural competencies. According to their description of the cross-cultural situation, we use cognitive, affective and behavioral skills. We perceive, understand, feel, and coincide based on the situation. Accordingly, Bennett [4] states that no behavior is separate from thinking and feeling. He further developed the terms of mindset and skillset as the main component of intercultural communication. The term mindset refers to an individual awareness of operating in a cultural context, where are usually involved conscious knowledge of the own culture, frameworks for creating useful cultural contrasts specifically communication styles or cultural values, and a clear understanding of how to use cultural generalizations without stereotyping. On the other hand, intercultural skillset includes the ability to analyze interaction, predict misunderstanding, and behavior. The skills can be thought of like the expanded repertoire of behavior-a repertoire that includes behavior that is appropriate to individual's own culture, but which does not exclude an alternative response that might be more appropriate in another culture [6].

In cognitive competencies we include the knowledge, abilities, and skills that shape our mental system. This includes self-concept, cultural identity, understanding of foreign cultures, prevention of prejudices and stereotypes. Among the affective competencies, we consider as the most crucial development of intercultural sensitivity and adaptability, empathy, interpersonal relationships and cross-cultural experience. Intercultural sensitivity could be defined as a willingness to admit that our view of the world is only one of many but not the determining one [4]. The issue of intercultural sensitivity has become an important topic, especially among the North American researchers. Let us also mention one of the most well-known models of intercultural sensitivity, the Bennett Model of Intercultural Sensitivity - DMIS. In his view, intercultural sensitivity is described as a developmental process in which the individual can change to affective, cognitive, and behavioral level. The first three levels are defined as ethnocentric (Denial, Defense, Minimization) the last three as ethnorelative (Acceptance, Adaptation, Integration) [6]. From the author's point of view, DMIS can be used to identify the stage of an individual's cultural sensitivity and thus to predict attitudes and behaviors common to people at a specific cognitive stage. However, we agree with Perry and Southwell [7] that Bennett model assumes that individuals develop intercultural sensitivity in a stepwise fashion, with excluding the possibility that individuals may move backward as well as forwards in the six stages. The authors also point to the experience of many individuals who have lived abroad suggesting that the process of adopting the final step of DMIS, is not as simple as Bennett states.

Chen [8] also developed the concept of intercultural sensitivity and suggested seven key features that an individual should develop appropriately to become culturally sensitive. He emphasized the need for an individual to work on his self-esteem, as he pointed to the fact that culturally sensitive individuals tend to have higher self-esteem, leading to greater self-confidence in interacting with other people. Another key feature is the self-monitoring of behavior or self-regulation. As some authors suggest, self-regulation is an intrapsychic process that requires individuals to observe and control their behavior, emotions, and thoughts, which can vary according to a specific situation. During this process, an individual transforms these skills into the skills needed to handle situation [9]. Another feature he mentions is openness, which he understands as the willingness of individuals to openly and properly explain and accept other explanations. Other constructs also mentioned are the ability of empathy, which has long been the central element of the development of intercultural sensitivity. We interpret empathy as an ability to capture and understand the contents of the other person's consciousness, the capacity to feel the current individual's experience and adaptively to his emotions to react. Goleman [10] states that developed empathy is also characterized by the ability to recognize pretentious feelings as well as lies. Hartl [11] understands empathy as "the ability to empathize with the feelings and actions of another person; is part of the emotional intelligence that can be developed by training. " Rogers [12] also states that empathy may be innate, but that it is relatively easy to get it in a stimulating and empathic environment. The last two features Chen mentions are interaction involvement and non-judgment. Interaction Involvement understands the ability of an individual to engage in different situations and adequately respond to various stimuli. Being a non-judgment person presupposes, among other things, to suppress its stereotypical ways of thinking and to evaluate, as well the ethnocentric view of the world. As Bennett mentions, stereotypes of both types of positive or negative can be problematic in intercultural communication. They can give us a false perception of understanding our communication partners [4]. Chen and Starosta [1] have developed four personal attributes, which form the foundation of the affective component on intercultural communication competence. These attributes include the self-concept, open-mindedness, nonjudgmental attitudes, and social relaxation. They enable an individual to be sensitive sufficiently during intercultural interactions to acknowledge and respect cultural differences. Behavioral competencies include the ability of intercultural communication as well as the ability to cooperate in an intercultural team and the solution of intercultural conflicts. In general, development of intercultural competencies is a 
complex issue, where we do not only perceive the knowledge, skills, and abilities, that can be gained or learned, but rather the improvement of certain personality traits, which lead to the achievement of success in an intercultural situation. However, to become an interculturally competent, author Barna says, that an individual must overcome such stumbling blocks, which can, for example, include feelings of anxiety when communicating with those from different cultural backgrounds [13]. Among these stumbling blocks, the assumption of similarity, language differences, misinterpretations of non-verbal behavior, the presence of prejudices and stereotypes, the tendency to evaluate or anxiety are included.

\section{B. Intercultural Competencies in the Czech Republic}

The issue of intercultural competencies is a relatively new phenomenon in the Czech Republic. While the Czech Republic has been the target country for many immigrants in recent years, the issue of integration of immigrants and related intercultural communication is not resolved to the extent, as is in the other countries in Western Europe or North American countries. Another problem is the professional training of employees in assisting professions or in education, who did not have the opportunity to acquire the necessary competencies in formal education. It can be said, that employees are not systematically prepared and qualified to fully interact in an intercultural situation, to fully understand ongoing processes or adequately respond to new conditions. The lack of competencies when working with, for example, culturally different pupils or clients may appear to bring inadequate generalization when assessing their manifestations. Alarming problem is the lack of research in this field. There are not many researchers who are systematically interested and involved in the issue of intercultural competencies. The interest has increased over the last 15 years, as is evidenced by several studies. For example, Hladík and Chudý [14] conducted research, where they compared the level of multicultural competences of elementary school pupils. Hladík [15] has also examined the relationship between the cognitive and affective component of intercultural competencies by elementary school pupils and students of secondary schools and universities in 2011. Other authors who deal with this issue on a long-term and systematic basis are authors Morgensternová and Šulová [13], [16], with their focus mainly on intercultural psychology and the development of intercultural competencies. Another Czech author, Průcha [17], [18] focuses on intercultural psychology and multicultural education.

\section{RESEARCH DESIGN}

The main objective of this pilot research is to analyze the preparedness of the university students of Social Pedagogy to work in assisting professions, where is also expected to communicate with people from different cultural backgrounds. Acquisition of adequate intercultural skills can significantly contribute to successful management of future job responsibilities. We believe that the reason for choosing this field of study is the student's interest in gaining knowledge about different cultures and self-education in this direction. Hladík also presumes [19] that students who choose to study Social pedagogy are preparing for contact and work in a culturally diverse environment. However, this multicultural training is not unified and sometimes can be significantly different regarding goals and resources. Some of the students have already gained multicultural experience through their employment opportunities. Due to the actual circumstances, first and foremost, we wanted to clarify, if there are any differences in intercultural competences between students with work experience in a multicultural environment and students without work experience in a multicultural environment. Another objective was to ascertain the relationship between selected personality skills that can predict successful adaptation in a cross-cultural environment.

The pilot research was conducted during the study year 2017/2018 at Tomas Bata University in Zlín, and its design is conceived as a quantitative one. The research sample was deliberate and was selected based on the available choice. The research sample consisted of university students of Social Pedagogy at the Faculty of Humanities at Tomas Bata University in Zlín ( $\mathrm{N}=116$ valid). 86 respondents were females, 30 respondents' males. Considering the fact, that university studies are also attended by students in external form of study, the age range ranged from 19 to 52 with the average age of the respondents 23, 11 years (SD 6,14, for women the average age 22,66 (SD 5, 55), whereas for men, the average age was 24.4, ranging from 19 to 43 years (SD 7.54). The students filled in the questionnaires using the "paper - pencil" method during the school classes. Due to the personal instruction with completing the questionnaire, none of them was excluded.

We measured the preparedness of students by using the following methods:

The socio-demographic questionnaire which included demographic data such as age, gender, or work experience in a multicultural environment. We did not specify the experience of working in a multicultural environment because we did not need more detailed information for our research.

To ascertain the primary goal of our research, we used the CCAI - Cross-Cultural Adaptability Inventory by Colleen Kelley, Ph.D. and Judith Meyers, PsyD. [20]. The CCAI Cross-Cultural Adaptability Inventory is a self-assessment tool that provides information to an individual about its potential for intercultural efficiency and adaptability. Kelley and Meyers define four areas of skills: Emotional Resilience, Flexibility/Openness, Perceptual Acuity and Personal Autonomy that can predict success in intercultural adaptability and, moreover, these skills are identifiable and can be improved in intercultural training. We were equally interested in the gender differences among the students in gaining intercultural competencies. We also observed whether is a statistically significant relationship between the chosen dimensions. 
Before we started to implement the research, we borrowed the Czech translation of the Cross-Cultural Adaptability Inventory - CCAI from the National Institute of Education in Prague $^{1}$, by whom we also received informed written consent to use the instrument.

The Cross-Cultural Adaptability Inventory - CCAI contains a total of 50 items identifying the degree of intercultural adaptability. As mentioned above, this instrument evaluates four categories of intercultural adaptability - Emotional Resilience (ER), Flexibility and Openness (FO), Perceptual Acuity (PA) and Personal Autonomy (PA). There are six possible answers for each questionnaire item. The responses are shown in a range from 1 to 6 , with number 1 being "definitely not true", number 6 being "surely true." Nine of these items have the opposite direction of scoring. The sum of the results for each scale is the sum of the response values per item.

The dimension Emotional Resilience focuses on those aspects of intercultural experience that can cause unpleasant feelings. The results in this area point to the extent to which a person can regulate their feelings, emotions and maintain emotional balance. This dimension also identifies the extent to which an individual can cope with negative feelings and respond positively to new experiences. This dimension is the largest of all and contains a total of 18 items. Individual items are categorized into the following groups: Balancing with the situation, especially with stress and ambiguity, Acceptance of deficiencies and mistakes and recuperation, Testing new things and experiences, Interaction with people in new or unfamiliar situations.

The dimension Flexibility/Openness measures the extent to which an individual can find pleasure in different ways of thinking and behavior that are essential in intercultural communication and experience. Individual items in this category focus on responses to people, situations, and skills that are different from those encountered by an individual in life. This category contains a total of 15 items that are grouped into the following groups: Affection and openness to unknown people and experiences, Interest in people and the desire to learn, Tolerance, understanding and non-judging attitude towards people who are different, Flexibility of approaches to new skills.

The dimension Perceptual Acuity perceives the extent to which the individual pays attention to the verbal and non-verbal aspects of communication that can be entirely different in the intercultural environment and their ability to accurately interpret the different style of communication. This category contains 10 items that describe the behavior that is useful for intercultural dialogue.

The dimension of Personal Autonomy associated with the concept of self-consciousness measures the extent to which the individual has developed a personal system of values and beliefs by which he can function with sufficient self-confidence in an

\footnotetext{
${ }^{1}$ www.nuv.cz
}

unfamiliar environment. Besides, this scale determines to what extent an individual can respect a different way of life and other people. This category contains a total of 7 items and focuses on personal identity, values, beliefs, and self-awareness in the context of an unknown.

In the first phase, the data obtained from the Inventory was manually evaluated. Subsequently, the data was entered in MS Excel 2013, where formal and logical data control was then performed. Further data processing was conducted through the statistical software STATISTICA, version 12 [21]. Analysis of the distribution of individual results confirmed the normal distribution of data, and therefore parametric statistics were selected, namely descriptive statistics, two-sample T-test and Pearson correlation. The tests were performed at a 5\% level of significance.

\section{RESULTS}

In the first phase, we will present the results based on gender differences and work experience in a multicultural environment. In the next phase, we will present the results of the Pearson correlation between the individual categories of the Inventory of Intercultural Adaptability concerning the work experience in a multicultural environment.

Gender-based Comparison of Results Among the Students of Social Pedagogy

Table 1 presents the results of the T-test in the assessment of gender differences in the individual categories of the questionnaire CCAI. From the presented results it can be stated that there is no significant difference in the monitored categories based on the respondents' gender. However, based on averages, we can see a slight tendency, where men score better in the categories: Emotional Resilience and Flexibility.

TABLE I

GENDER-BASED COMPARISON OF RESULTS AMONG THE STUDENTS OF SOCIAL PEDAGOGY

\begin{tabular}{|c|c|c|c|c|c|c|c|c|c|c|c|}
\hline \multirow[b]{2}{*}{ Variable } & \multicolumn{11}{|c|}{ T-tests; Grouping: by gender } \\
\hline & $\begin{array}{c}\text { Mean } \\
\text { females }\end{array}$ & $\begin{array}{l}\text { Mean } \\
\text { males }\end{array}$ & t-value & df & $\mathrm{p}$ & $\begin{array}{c}\text { Valid } \\
\mathrm{N} \\
\check{z}\end{array}$ & $\begin{array}{c}\text { Valid } \\
\mathrm{N} \\
\mathrm{m}\end{array}$ & $\begin{array}{c}\text { Std.Dev } \\
\check{z}\end{array}$ & $\begin{array}{c}\text { Std.Dev } \\
\cdot \\
\mathrm{m}\end{array}$ & $\begin{array}{c}\text { F-ratio } \\
\text { Variance } \\
\mathrm{s}\end{array}$ & $\begin{array}{c}\mathrm{p} \\
\text { Variance } \\
\mathrm{s}\end{array}$ \\
\hline $\begin{array}{l}\text { Emotional } \\
\text { Resilience }\end{array}$ & 75,0000 & 78,0333 & 1,58376 & $\begin{array}{r}11 \\
4 \\
\end{array}$ & $\begin{array}{r}0,11601 \\
9 \\
\end{array}$ & 86 & 30 & 9,83989 & 6,07700 & 2,621820 & 0,004507 \\
\hline $\begin{array}{l}\text { Flexibility/Openne } \\
\text { ss }\end{array}$ & 61,4070 & 63,3333 & 1,17773 & $\begin{array}{r}11 \\
4 \\
\end{array}$ & $\begin{array}{r}0,24135 \\
7 \\
\end{array}$ & 86 & 30 & 7,80404 & $\begin{array}{l}4,44327 \\
7,45\end{array}$ & 1,099287 & 70,796923 \\
\hline Perceptual Acuity & 43,8140 & 44,0000 & 0,16966 & $\begin{array}{r}11 \\
4\end{array}$ & $\begin{array}{r}0,86558 \\
0\end{array}$ & 86 & 30 & 5,23902 & \begin{tabular}{|l|l}
2 & 4,96887
\end{tabular} & 1,111694 & 0,769187 \\
\hline $\begin{array}{l}\text { Personal } \\
\text { Autonomy }\end{array}$ & 31,4767 & 31,9333 & 0,55319 & $\begin{array}{r}11 \\
4 \\
\end{array}$ & $\begin{array}{r}0,58121 \\
8 \\
\end{array}$ & 86 & 30 & 4,05180 & 3,38285 & 1,434600 & 0,273609 \\
\hline Total score & $\begin{array}{r}211,697 \\
7\end{array}$ & $\begin{array}{r}217,300 \\
0\end{array}$ & | & $\begin{array}{r}11 \\
4\end{array}$ & $\begin{array}{r}0,23468 \\
1\end{array}$ & 86 & 30 & $\begin{array}{r}23,2935 \\
6\end{array}$ & \begin{tabular}{|r|r|}
5 & 18,2268 \\
6
\end{tabular} & 1,6 & 0,136746 \\
\hline
\end{tabular}

Comparison of Results in Each Category of the Questionnaire Based on Work Experience in a Multicultural Environment

Table 2 presents the results of the responses in each category of the CCAI questionnaire concerning the work experience of respondents in a multicultural environment. Based on the 
comparison of groups with work experience in a multicultural environment and groups without any experience in a multicultural environment, a significant difference was found in all the monitored categories. It means that students who are having personal work experience in a multicultural environment scored significantly better in all the controlled areas. In other words, students with a multicultural experience gain greater emotional resilience, flexibility, and openness in thinking and negotiation, have a better ability to communicate and are more able to respect a different way of life and other people than students who have lack of any personal experience with work in multicultural environment.

TABLE II

COMPARISON OF RESULTS IN EACH CATEGORY OF THE QUESTIONNAIRE BASED ON WORK EXPERIENCE IN A MULTICULTURAL ENVIRONMENT.

\begin{tabular}{|c|c|c|c|c|c|c|c|c|c|c|c|}
\hline \multirow[b]{2}{*}{ Variable } & \multicolumn{11}{|c|}{ T-tests; Grouping: by work experience in a multicultural environment } \\
\hline & $\begin{array}{c}\text { Mean } \\
\text { no work } \\
\text { experience }\end{array}$ & $\begin{array}{c}\text { Mean } \\
\text { with work } \\
\text { experience }\end{array}$ & $\begin{array}{c}\mathrm{t}- \\
\text { value }\end{array}$ & df & $\mathrm{p}$ & $\begin{array}{c}\text { Valid } \\
\mathrm{N} \\
\text { ne }\end{array}$ & $\begin{array}{c}\text { Valid } \\
\mathrm{N} \\
\text { ano } \\
\end{array}$ & \begin{tabular}{|c|} 
Std.D \\
ev. \\
ne
\end{tabular} & \begin{tabular}{|c|} 
Std.D \\
ev. \\
ano \\
\end{tabular} & $\begin{array}{c}\text { F-ratio } \\
\text { Varian } \\
\text { ces }\end{array}$ & \begin{tabular}{|c}
$\mathrm{p}$ \\
Varian \\
ces \\
\end{tabular} \\
\hline $\begin{array}{l}\text { Emotional } \\
\text { Resilience }\end{array}$ & 71,7761 & 81,5333 & $\begin{array}{r}6,6364 \\
9\end{array}$ & 11 & $\begin{array}{r}0,0000 \\
00\end{array}$ & 67 & 45 & $\begin{array}{r}8,6178 \\
5\end{array}$ & $\begin{array}{r}5,8371 \\
8\end{array}$ & $\begin{array}{r}2,1796 \\
70\end{array}$ & $\begin{array}{r}0,0069 \\
70 \\
\end{array}$ \\
\hline $\begin{array}{l}\text { Flexibilty/Open } \\
\text { ness }\end{array}$ & 58,4776 & 66,6000 & 6,4053 & $\begin{array}{r}11 \\
0\end{array}$ & $\begin{array}{r}0,0000 \\
00\end{array}$ & 67 & 45 & 6,9 & $\begin{array}{r}5,9022 \\
3\end{array}$ & $\begin{array}{r}1,4042 \\
78 \\
\end{array}$ & $\begin{array}{r}0,2328 \\
47 \\
\end{array}$ \\
\hline $\begin{array}{l}\text { Perceptual } \\
\text { Acuity }\end{array}$ & 41,8955 & 46,6222 & 5,2824 & $\begin{array}{r}11 \\
0\end{array}$ & $\begin{array}{r}0,0000 \\
01\end{array}$ & 67 & 45 & 5,2227 & $\begin{array}{r}3,6010 \\
7\end{array}$ & $\begin{array}{r}2,1034 \\
45\end{array}$ & $\begin{array}{r}0,0098 \\
93\end{array}$ \\
\hline \begin{tabular}{|l} 
Personal \\
Autonomy
\end{tabular} & 30,2537 & 33,488 & $\begin{array}{r}4,6620 \\
5 \\
\end{array}$ & 0 & $\begin{array}{r}0,0000 \\
09 \\
\end{array}$ & 67 & 45 & 3,6653 & $\begin{array}{r}3,5007 \\
9\end{array}$ & $\begin{array}{r}1,0962 \\
09\end{array}$ & $\begin{array}{r}0,7544 \\
88\end{array}$ \\
\hline tal & 202,4030 & 228,24 & $\begin{array}{r}7,4269 \\
9\end{array}$ & & $\begin{array}{r}0,0000 \\
00\end{array}$ & 67 & 45 & $\begin{array}{r}19,832 \\
68\end{array}$ & $\begin{array}{r}14,991 \\
14\end{array}$ & $\begin{array}{r}1,7502 \\
23\end{array}$ & $\begin{array}{r}0,0503 \\
15\end{array}$ \\
\hline
\end{tabular}

The Relationship Between Each Category of the Questionnaire for the Whole Sample

Table 3 presents the results of the Pearson correlation between each category of CCAI questionnaire for the entire set of respondents. The table shows that there is a significant positive relationship between emotional resilience and flexibility. In other words, individuals who can control their emotions are more open and show a positive attitude towards new people. Also, emotional resilience is positively related to higher ability to adequately communicate in a multicultural environment and with a higher score of personal autonomy. It means that people with high values of individual freedom do not lose their own identity when they encounter another culture, but they have strong conscious of who they are, they have respect for themselves and others. However, there was no evidence of a significant relationship between the age and the individual categories of the questionnaire.
TABLE III

THE RELATIONSHIP BETWEEN EACH CATEGORY OF THE QUESTIONNAIRE FOR THE WHOLE SAMPLE

\begin{tabular}{|c|c|c|c|c|c|c|}
\hline \multirow[b]{2}{*}{ Variable } & \multicolumn{6}{|c|}{ All Groups Correlations. Marked correlations are significant at $\mathrm{p}<, 05000$} \\
\hline & Age & $\begin{array}{l}\text { Emotional } \\
\text { Resilience }\end{array}$ & $\begin{array}{c}\text { Flexiblity/Oppenn } \\
\text { ess }\end{array}$ & $\begin{array}{c}\text { Perceptual } \\
\text { Acuity } \\
\end{array}$ & $\begin{array}{c}\text { Personal } \\
\text { Autonomy }\end{array}$ & $\begin{array}{l}\text { Total } \\
\text { score }\end{array}$ \\
\hline Age & \begin{tabular}{|r|}
1,00000 \\
0
\end{tabular} & 0,102240 & 0,004072 & $-0,001156$ & $-0,011572$ & 0,041078 \\
\hline \begin{tabular}{|l|} 
Emotional \\
Resilience
\end{tabular} & $\begin{array}{r}0,10224 \\
0\end{array}$ & 1,000000 & 0,685957 & 0,638446 & 0,638539 & 0,909808 \\
\hline $\begin{array}{l}\begin{array}{l}\text { lexiblity/Oppenn } \\
\text { ess }\end{array} \\
\end{array}$ & $\begin{array}{r}0,00407 \\
2 \\
\end{array}$ & 0,685957 & 1,000000 & 0,642370 & 0,504448 & 0,867888 \\
\hline Perceptual Acuity & $\begin{array}{r}0,00115 \\
6\end{array}$ & 0,638446 & 0,642370 & 1,000000 & 0,609375 & 0,825173 \\
\hline $\begin{array}{l}\text { Personal } \\
\text { Autonomy }\end{array}$ & $\begin{array}{r}0,01157 \\
2\end{array} \mid$ & 0,638539 & 0,504448 & 0,609375 & 1,000000 & 0,754739 \\
\hline Total score & \begin{tabular}{|r|}
0,04107 \\
8
\end{tabular} & 0,909808 & 0,867888 & 0,825173 & 0,754739 & 1,000000 \\
\hline
\end{tabular}

The Relationship Between each category of the Questionnaire Concerning Students with Work Experience in a Multicultural Environment

Table 4 presents the results of the individual correlations between the questionnaire categories in the sample of respondents who have experience in a multicultural environment $(\mathrm{N}=45)$. There was a significant positive relationship between age and emotional resilience and flexibility. With the increasing age of respondents, their emotional resilience increases, and they are more open to new people, ideas and ways of solving problems. As with the whole group, there was a significant positive relationship between emotional resilience and all other categories of the questionnaire.

\section{TABLE IV}

THE RELATIONSHIP BETWEEN EACH CATEGORY OF THE QUESTIONNAIRE CONCERNING WORK EXPERIENCE IN A MULTICULTURAL ENVIRONMENT

\begin{tabular}{|c|c|c|c|c|c|c|}
\hline \multirow[b]{2}{*}{ Variable } & \multicolumn{6}{|c|}{$\begin{array}{l}\text { Students with work experience in multicultural environment - correlations. } \\
\text { Marked correlations are significant at } p<, 05000 \mathrm{~N}=45\end{array}$} \\
\hline & Age & $\begin{array}{l}\text { Emotional } \\
\text { Resilience }\end{array}$ & $\begin{array}{c}\begin{array}{c}\text { Flexibility/Openn } \\
\text { ess }\end{array} \\
\end{array}$ & $\begin{array}{l}\text { Perceptual } \\
\text { Acuity }\end{array}$ & $\begin{array}{l}\text { Personal } \\
\text { Autonomy }\end{array}$ & $\begin{array}{l}\text { Total } \\
\text { score }\end{array}$ \\
\hline Age & $\begin{array}{r}1,000 \\
0\end{array}$ &, 3333 &, 3317 & , 1249 &,- 0544 & ,2777 \\
\hline \begin{tabular}{|l|}
$\begin{array}{l}\text { Emotional } \\
\text { Resilience }\end{array}$ \\
\end{tabular} &, 3333 & 1,0000 &, 5829 & ,5018 &, 5008 & ,8563 \\
\hline $\begin{array}{l}\text { Flexibility/Openne } \\
\text { ss }\end{array}$ &, 3317 & ,5829 & 1,0000 &, 5734 & ,3430 & ,8385 \\
\hline Perceptual Acuity &, 1249 & .5018 & ,5734 & 1,0000 & ,4098 &, 7570 \\
\hline $\begin{array}{l}\text { Personal } \\
\text { Autonomy }\end{array}$ & ,0544 & ,5008 & , 3430 & 4098 & 1,0000 & 6620 \\
\hline Total score & $\mid, 2777$ & ,8563 & ,8385 & ,7570 & ,6620 & 1,0000 \\
\hline
\end{tabular}

The Relationship Between Each Category of the Questionnaire Concerning Students without Work Experience in a Multicultural Environment

Table 5 shows the results of the students without work experience in a multicultural environment. The results obtained are similar to the results of the correlation for the whole set, namely that all four dimensions are closely related to each other and positively influence each other. 
TABLE V

THE RELATIONSHIP BETWEEN EACH CATEGORY OF THE QUESTIONNAIRE IN RELATION TO THE STUDENTS WITHOUT WORK EXPERIENCE IN A MULTICULTURAL ENVIRONMENT

\begin{tabular}{|c|c|c|c|c|c|c|}
\hline \multirow[b]{2}{*}{ Variable } & \multicolumn{6}{|c|}{$\begin{array}{l}\text { Students without work experience in a multicultural environment - correlations. } \\
\text { Marked correlations are significant at } \mathrm{p}<, 05000 \mathrm{~N}=67\end{array}$} \\
\hline & Age & $\begin{array}{l}\text { Emotional } \\
\text { Resilience }\end{array}$ & $\begin{array}{c}\text { Flexibility/Openn } \\
\text { ess }\end{array}$ & $\begin{array}{l}\text { Perceptual } \\
\text { Acuity }\end{array}$ & $\begin{array}{c}\text { Personal } \\
\text { Autonomy }\end{array}$ & $\begin{array}{l}\text { Total } \\
\text { score }\end{array}$ \\
\hline Age & $\begin{array}{r}1,000 \\
0\end{array}$ &,- 0482 & - 2376 &,- 1144 &,- 0512 &,- 1443 \\
\hline $\begin{array}{l}\text { Emotional } \\
\text { Resilience } \\
\end{array}$ &, 0482 & 1,0000 & ,5498 & ,5283 &, 5683 & ,8726 \\
\hline $\begin{array}{l}\text { Flexibility/Openne } \\
\text { ss }\end{array}$ &, 2376 & ,5498 & 1,0000 &, 5261 & ,3752 & ,7994 \\
\hline Perceptual Acuity &, 1144 &, 5283 &, 5261 & 1,0000 & ,5752 &, 7848 \\
\hline \begin{tabular}{|l} 
Personal \\
Autonomy
\end{tabular} &, 0512 & ,5683 & ,3752 & ,5752 & 1,0000 & ,7156 \\
\hline Total score & , 1443 & , 8726 & ,7994 & ,7848 &, 7156 & 1,0000 \\
\hline
\end{tabular}

\section{CONCLUSIONS}

In our study, we analyzed the preparedness of university students of Social Pedagogy to work in assisting professions, where, among others, is expected personal contact with members of different ethnic and national groups. Working in a culturally diversified environment is related to the acquisition of adequate intercultural skills which can significantly contribute to successful job fulfillment. Specifically, we were interested in the results of the four dimensions of the Inventory of Intercultural Adaptability - CCAI (Emotional Resilience, Flexibility / Openness, Perceptual Acuity, Personal Autonomy). The results did not show a significant difference in the monitored dimensions of the Inventory of Intercultural Adaptability based on the respondents' gender. However, based on the results of the average values, there is a slight tendency for men to score better than women concerning the categories Emotional Resilience and Flexibility / Openness. Similar results between males and females are most likely caused by growing up in similar family models and the fact that most respondents come from a close neighborhood where they share basically the same cultural environment.

The results also show as we predicted, that students who have work experience in a multicultural environment generally have better scores in all measured aspects of intercultural adaptability. In other words, students with personal work experience in a multicultural environment show greater emotional resilience, flexibility, and openness in thinking and acting, have a better ability to communicate and respect different lifestyles and other people than students who have been only exposed to their own culture. We can also see a significant positive relationship between age and emotional resilience and flexibility in respondents with work experience in a multicultural environment. It can be said that individuals who have been exposed to direct interaction with people from a different cultural environment acquire better intercultural skills are more versatile in communicating in a cross-cultural context and probably could better adapt to different life conditions that require different behavior patterns. We can regard as a significant discovery, that they can maintain their emotional balance in a new, unknown environment. They are also able to deal with uncertainty; thus, we suppose that they feel less anxious than the students with no experience.

The results we obtained are similar to the results of the 2001 research conducted by Kitzantas and Meyers, where the CCAI evaluation tool was also used. That study examined the role of study programs abroad on cross-cultural awareness among students [22]. The findings of their research have shown, that the study programs abroad contribute significantly to the preparation of students to function in a multicultural world and promote international understanding. Similar results were obtained in another research by Rundstrom Williams [23], namely that students who study abroad generally have better intercultural communication skills than students who do not study abroad. In other words, exposure to different cultures tends to be a better predictor of the development of cross-cultural communication skills. This means that intercultural confrontation and exposure to other cultures leads to the need to solve practical problems. We can conclude, that individuals who are exposed to direct cross-cultural experience increase their own ability to cope with stress and develop more flexible behavior, cultural empathy, and respect for other cultures.

This pilot research could not cover everything related to the issue of intercultural competencies. The study has also been limited regarding students' willingness to participate in piloting, as well as the need for improved research tools or a combination of qualitative and quantitative approaches, would probably yield better-value results. This study is our first impetus for furthermore in-depth exploration of this issue. It would also be interesting to compare student results at the beginning of the semester and after completing training in intercultural skills. However, the development of cross-cultural skills is a complex task, and we still have limited knowledge of what is the best way to develop individual competencies. We also agree with Perry and Southwell [7] that the issue of intercultural competencies should become one of the central tasks in the educational sciences as our world becomes more interconnected and multicultural.

\section{ACKNOWLEDGMENTS}

The article was created within the grant project GA CR 17-04816S The Dynamics of Self-Regulation in Socially Excluded Pupils.

\section{REFERENCES}

[1] G. Chen, W.J. Starosta, "Intercultural Communication Competence: A Synthesis," Annals of the International Communication Association, vol.19, no.1, pp.353-383,1996. 10.1080/23808985.1996.11678935

[2] P. Morvayová, D. Moree, Dvakrát měr, jednou řež, Praha: Varianty, Člověk v tísni, 2009.

[3] M. Morgensternová, L. Šulová, et al., Interkulturní psychologie: rozvoj interkulturní sensitivity, Praha: Karolinum, 2009. 
[4] M.R. Hammer, M.J. Bennett, and R. Wiseman, "Measuring Intercultural Sensitivity: The intercultural development inventory, "International Journal of Intercultural Relations, vol.27, pp.421-443, 2003. https://doi.org/10.1016/S0147-1767(03)00032-4

[5] A. Fantini, "Exploring and assessing intercultural competence, " $C S D$ Research Paper No. 07-01, St. Louis, MO: Washington University Center for Social Development, 2007.

[6] J.M. Bennet, M.J. Bennet, "Developing Intercultural Sensitivity: An Integrative Approach to Global and Domestic Diversity," The Intercultural Communication Institute Portland, Oregon, 2001.

[7] L.B. Perry, L. Southwell, "Developing intercultural understanding and skills: models and approaches," Intercultural Education, vol.22, no.6, pp.453-466,2011. DOI: 10.1080/14675986.2011.644948

[8] G. Chen, "A Review of the Concept of Intercultural Sensitivity." presented at the Biennial Convention of the Pacific and Asian Communication Association, Honolulu, HI, January,1997.

[9] S. Vávrová, K. Hrbáčková, and J. Hladík, Porozuměni procesu autoregulace u dètí a mladistvých v institucionální péči. Zlín: Univerzita Tomáše Bati ve Zlíně, 2015.

[10] D. Goleman, Emoční intelligence, Praha: Columbus, 1997.

[11] P. Hartl, Stručný psychologický slovník, Praha: Portál, 2004.

[12] C. R. Rogers, Způsob bytí: Kličová témata humanistické psychologie z pohledu jejího zakladatele, Praha: Portál,1998.

[13] M. Morgensternová, L. Šulová, L. Schöll, Bilingvismus a interkulturní komunikace, Praha: Wolters Kluwer, 2011.

[14] J. Hladík, Š. Chudý, "Komparace multikulturních kompetencí žáků ZŠ, “ Pedagogická orientace, vol.16, no.3, pp.46-52, 2006.

[15] J. Hladík, "Vztah kognitivní a afektivní složky multikulturních kompetencí, "Pedagogika, vol. 61, no.1, pp.53-65, 2011.

[16] M. Morgensternová, L. Šulová, et al, Interkulturní psychologie: rozvoj interkulturni sensitivity, Praha: Karolinum, 2007.

[17] J. Průcha, Multikulturní výchova, Praha: Triton, 2011.

[18] J. Průcha, Interkulturní psychologie, Praha: Portál, 2007.

[19] J. Hladík, Multikulturni kompetence studentů pomáhajicich profesí, Zlín: Univerzita Tomáše Bati ve Zlíně, 2014.

[20] C. Kelleyová, J. Meyersová, CCAI - Inventáŕ interkulturální adaptability, Minneapolis: NCS Pearson, 1995.

[21] StatSoft, S. T. A. T. I. S. T. I. C. A. (2012). 12 (2012): Copyright@ StatSoft.

[22] A. Kitsantas, J. Meyers, "Studying Abroad: Does It Enhance College Student Cross-Cultural Awareness? "Annual Meeting of the San Diego State University and the U.S. Department of Education Centers for International Business Education and Research (CIBER 2001), San Diego, CA, March 28-31,2001.

[23] W.T. Rundstrom, "Exploring the Impact of Study Abroad on Students. Intercultural Communication Skills: Adaptability and Sensitivity," Journal of Studies in International Education, vol.9, no.4, pp.356-371, 2005. DOI: 10.1177/1028315305277681.

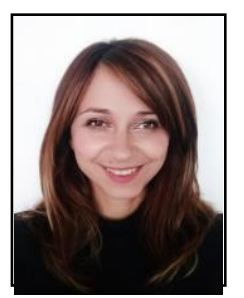

Irena Balaban Cakirpaloglu was born in Skopje, Republic of Macedonia on September 15, 1979. She is a graduate of master's degree in Fine Arts and Education at the Palacky University in Olomouc, Czech Republic in 2003; Doctor of Philosophy in the field of Anthropology at the Palacky University in Olomouc, Czech Republic in 2007. She had been employed at the National Institute of Education, Section for Educational and Psychological Guidance, Prevention and Institutional Education, where she had worked as a counselor providing methodological and counseling support for elementary and secondary schools. She had also worked as an Assistant Professor at the Palacky University in Olomouc, Czech Republic and University of Lower Silesia, Wroclaw, Poland with focus on multicultural education and diversity in education. Currently, she works as an Assistant Professor at Tomas Bata University in Zlin, Czech Republic. She has been a member and coworker in many national projects and researches in the Czech Republic.

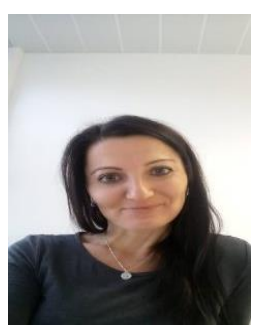

Karla Hrbackova was born in Czech Republic on November 3rd, 1978. She is a graduate master's degree in Faculty of Education at the Palacky University in Olomouc, Czech Republic in 2001; Doctor of Philosophy in the Field of Education at Masaryk University in Brno, Czech Republic in 2010. She had worked as a vice dean for research and creative activities and a head of Research Centre at Faculty of Humanities, Tomas Bata University in Zlín, which she helped to establish in 2012. She had also worked as a primary school teacher. Currently, she works as an Assistant Professor at the Department of Pedagogical Sciences at Humanities, Tomas Bata University in Zlín. She is interested predominantly in the matter of self-regulation, autonomy, self-determinated behaviour and social relations in the classroom. She is a main researcher and team leader working on a Czech Science Foundation project Self-Regulation in Socially Excluded Pupils. 